\title{
A qualitative analysis of EFL learners' task-generated discourse
}

\author{
Hazleena Baharun ${ }^{1}$,Abd. Razak Zakaria ${ }^{2}$ \\ ${ }^{1}$ Faculty of Major Language Studies, UniversitiSains Islam Malaysia (USIM) \\ ${ }^{2}$ Faculty of Education, University of Malaya, Malaysia
}

Email address:

hazleena@usim.edu.my(H. Baharun), abdrazakzakaria@yahoo.com(A. R. Zakaria)

To cite this article:

HazleenaBaharun, Abd. RazakZakaria. A Qualitative Analysis of EFL Learners' Task-Generated Discourse. Education Journal. Vol. 2, No. 6, 2013, pp. 242-248. doi: 10.11648/j.edu.20130206.16

\begin{abstract}
This study examined oral discourse generated by learners of English as a foreign language (EFL) using two different communication task types i.e. jigsaw and decision-making. It investigated how the learners approached and processed the tasks and how they interacted during task completion. The data for the study comprised transcribed recordings of learner interactions working on given tasks. They were qualitatively analysed focusing on the cognitive and social processing. Findings showed that both task types promoted episodes of negotiated interaction when the participants attempted task completion. However, close examination showed that the participants engaged in more intensive negotiations which were exploratory in nature and highly collaborative during decision-making task completion than during task completion of the jigsaw task type. The results suggest that different task types elicited different kinds of interaction from the learners and how the participants approached and processed the tasks shaped the kind of learner interactions they generated.
\end{abstract}

Keywords: Oral Discourse, Negotiated Interaction, Exploratory Talk, Communication Tasks

\section{Introduction}

In second language learning, interaction has always been regarded as important in a language classroom as it is believed that language is best learned and taught through interaction. Interaction is important because it contributes to gains in second language (L2) acquisition and numerous studies have revealed the importance of interaction for second language learning (e.g. de la Colina\& Garcia Mayo, 2007; Garcia, 2007; Long, 1983; Mackey \&Gass, 2006; Pica \& Doughty, 1985). When learners interact, they engage in multiple activities such as repeating themselves, providing explanations and giving details in order to ensure their ideas and messages get across (Olsen \& Kagan, 1992).

Using task-based instruction is one way of providing learners with opportunities to interact. In task-based instruction, learners interact with one another when performing the tasks. In this case, tasks become the driving force for language use and they are used as stimulus for generating talk among learners (Swain \&Lapkin, 1998). Many studies have shown that the use of tasks in language classrooms provides opportunities for learners to interact(Ellis, 2004; Kowal\& Swain, 1997; Pica, Kanagy \&
Falodun, 1993; Swain, 1995, 1998; Swain \& Lapkin, 1995, 1998, 2000, 2001).

Both Long's (1985) Interaction Hypothesis and Swain's (1985) Output Hypothesis support the use of communication tasks in the L2 classroom. According to Long, modifications made by learners when they interact facilitate second language acquisition. These include both conversational and linguistic modifications. It is believed that these modifications can be encouraged through the use of communication tasks (Pica et al., 1993). Swain's (1985) Output Hypothesis claims that when learners produce language (output), not only that they focus on the content of their output; they may be forced to focus on syntax and morphology of the target language as well. It is believed that the use of communication tasks in the L2 classroom would promote such negotiation (Swain, 2001; Swain \&Lapkin, 1998).

\subsection{Tasks and Negotiated Interactions}

Communication, interaction and negotiation are argued to be facilitative for language acquisition. It is largely 
accepted that opportunities for interaction and negotiation for meaning are imperative for learners to progress in the L2 learning process. Researchers in the field of Second Language Acquisition (SLA) argue that meaning negotiation plays an important role in SLA. This is because it provides opportunities for interactional modifications to occur during negotiation and this increases input comprehensibility (Long \& Robinson, 1998). In other words, meaning negotiation creates condition for second language (L2) development because it "offers learners opportunities to obtain L2 input that is adjusted to their comprehension needs, get feedback on production, produce modified output, and focus learners' attention to relevant L2 structural and semantic relationships" (Garcia, 2007). Research on tasks demonstrates that the use of tasks in second language classroom promotes communication, interaction and negotiation (e.g. Gass\&Varonis, 1994; Iwashita, 2003; Mackey, Oliver \&Leeman, 2003; Pica et al., 1993).

Empirical studies indicate that certain task types may promote more negotiated interactions than others (e.g. Blake, 2000; Long, 1996; Nakahama, Tyler \& Van Lier, 2001; Pica, 1992; Pica et al., 1993; Smith, 2003; Tabatabaei, 2009). However, quoting Nakahama et al. (2001), "comparing the quantity of repair negotiation across tasks thus does not seem to tell the whole story" of the negotiated interactions generated across task types as "attending only to the overall numbers of repair negotiations masks important discourse dynamics and therefore masks important learning opportunities beyond the ideational or informational level". While a quantitative analysis of the negotiation episodes has its contribution, a qualitative analysis of the negotiation episodes might enable SLA researchers to examine the dynamics of the discourse and identify language learning opportunities as learners engage in task completion (Nakahama et al., 2001). Thus, this study examines learner interactions generated by the participants of the study as they engaged in the completion of two communication task types (jigsaw and decisionmaking) focusing on how they approached and processed the tasks. It addresses the following research question: What oral discourse is generated through the use of different communication task types?

\section{Methodology}

\subsection{Participants}

An intact class of 18 English as a foreign language (EFL) participants (six males and twelve female) from a public university in Malaysia participated in the study. Their ages ranged from 20-22 years old. They all came from religious secondary schools and shared the same L1 which was Malay language. They also had studied English as a subject in school for at least 11 years (6 years during primary education and 5 years during secondary education). The participants were put in groups of three.

\subsection{Tasks}

Two types of communication tasks were chosen for this study. They were the jigsaw and the decision-making task types. The tasks were chosen due to their different characteristics and capacity to elicit episodes of meaning negotiation. They were adapted and redesigned based on the characteristics proposed by Pica et al. (1993).

\subsection{Procedure}

This study adopted a qualitative approach both in the collection and analysis of the data. Learner interactions were gathered and examined qualitatively. By using the qualitative approach in the collection and analysis of the data, the researcher was able to gain in-depth information useful for this study.

\subsection{Data Analysis}

A three-level parallel analysis was adapted with modifications to analyse the oral discourse produced by the participants (Kumpulainen\& Wray, 2002). This was to examine the kinds of negotiated interactions generated by the participants, and how they approached and processed the different communication task types given to them. Hence, data were examined from two aspects; the cognitive processing and the social processing. The cognitive processing provided an understanding on how the participants approached and processed the tasks, whether their interactions were exploratory in nature or otherwise while the social processing provided an understanding on how the participants interacted during task completion.

\section{Results}

\subsection{Exploratory Vs Procedural}

What oral discourse is generated through the use of different communication task types?

Due to the nature of the jigsaw task in which none of the team members had total access to the information and each member held only a portion of the total information; they took charge and began asking others what information they had with them (Excerpt 1, lines 28 \& 30). The aim was to gather as much information as possible from each participant in the team. Thus, their learner interactions illustrated procedural handling of the information.

Excerpt 1 Jigsaw (Procedural Handling of Information) Aina: $\quad$ So what your paragraph is about? (line 28)

Speaker 3: The main point? I think the main point is about tide, right?

Aina: Ok, expert group B? (line 30)

Speaker 4: From our group B, I get rrr... plant in the sea...rrr...are usually called seaweed and it different with plant, with plant on land because it is not here, not have flower. And user of seaweed rrr...for animals. (It is and 
live) and also for women are for food, rrr...fertilizers, medicine and many other user.

Speaker 5: And I from group C I get, rmmm... about tide pools, where the small fish, starfish, crab and (sea) live in tide pool. And the last paragraph rrr...tell that we must protect our...earth. That's mean the...habitat of the fish. On the sea. Live in the sea. (J1/Red/28-39)

Even though their initial focus was to gather as much information as they could from each participant in the team, which resulted in procedural kind of interaction, the participants soon realized that they needed to understand the information totally before they could actually work toward achieving their goals. They became aware that to complete the tasks was not simply by gathering information from one another. Thus, their learner interactions changed to an exploratory one. This exploratory nature of interaction was characterized by intensive negotiation as the participants jointly investigated the materials to create meaning and test solutions. Their learner interactions then turned collaborative with evidence of intensive negotiation in order to comprehend the information. This is exhibited in Excerpt 2.

In Excerpt 2, Mohd attempted to explain to his team the information that he had gathered earlier regarding the seashore. Episodes of intensive negotiation began when Hartini found that she did not understand the information and began interrupting, asking for clarification (line 20). Mohd tried very hard to explain further and make himself understood. These episodes of negotiation continued as the participants needed to comprehend the content of the passage before they could jointly create and test solutions for task completion (e.g. lines 31-32, 38-40, 42-44, 46 \& 48-51). The episodes of intensive negotiation were signaled using the sentence 'Sorry to interrupt, can you explain', indicating that the participants needed more information or explanation (lines 20, $27 \& 33$ ). These were followed by joint investigation and joint meaning-making, and elaborate explanation shared by the participants (lines 21-22, 28 \& 34).

Excerpt 2 Jigsaw (Exploratory)

Mohd: Ok, this the unit area where the sea and land meet is called the sea shore sometime the shore you know the and shore.

Hartini: $\quad$ Sorry to interrupt, can you explain? (line 20)

Mohd: Ok, this earth has unit area, what the unit area? Unit area is sea and land meet sea and land meet. This we call. (lines 21-22)

Hartini: When they meet it call? (line 23)

Mohd: $\quad$ Sea shore or sometimes we call shore sea shore this mean sea also. (line 24)

Teacher: Shore sometimes.

Mohd: Shore sometimes. Every shore or sea is different and it show every sea.
Hartini: Sorry can you explain? I don't understand. (line 27)

Mohd: $\quad$ Ok, every shore is different and each and every shore. (line 28)

Jani: $\quad$ Each shore, there has many shores, each shore is different, shore, shore, shore from others. (lines 29-30)

Mohd: Every sea is different and every sea constantly changing or often changing, always change. (lines 31-32)

Jani: $\quad$ Sorry to interrupt, can you explain? Sorry.(line 33)

Mohd: Ok, every sea is different and every sea is always change. (line 34)

Jani: $\quad$ Every sea always change. (line 35)

Mohd: Always changing. (line 36)

Jani: What change? Sea? (line 37)

Mohd: Ok, if you go to beach at the same time for two days you will see different animals and plants in different place, you go this sea you see other animal, you go to PulauTioman these animals. (lines 38-40)

Jani: $\quad$ Ok.

Mohd: The waves will be different waves like Tsunami waves, will be different each day, you will see different objects by the power of the sea, sea. (lines 42-44)

Jani: $\quad$ Wave? (line 45)

Mohd: Wave coming up and then bring like pearl.(line 46)

Jani: $\quad$ In sea we have like, ok (giggle).

Mohd: If you stay at the sea shore, if you stay at the sea, you will know the sea coming up to the land or moving from the land. This is we call tide. Ok, (height) tide when the water come and low tide when moving away, ok go back. Tide are create by the moon and the sun. (lines 4851)

(J1/Brown/18-51)

A different kind of learner interactions was observed when the participants engaged in the decision-making task completion. They engaged in exploratory interactions where they interacted spontaneously, asked questions, provided answers to one another and shared opinions and ideas. The exploratory interactions were characterized by planning and experimenting. Excerpt 3 shows the exploratory interaction generated during decision-making task completion. In this episode, the participants wanted to ensure that they understood the meaning of words correctly before working on completing the task. When providing responses to the others in the team, they took the effort to provide explanation, give clarification, share opinions and translate words that the others did not understand. When Salim responded to the questions from the others in his team, he did not just translate words they did not understand or give direct answers. Instead, he provided 
explanation to ensure that him team comprehended correctly (e.g. lines 270-272, 300-301, 305-306 \& 310-311). Together, they explored the meaning of words they did not understand in order to gain joint understanding.

$\begin{array}{ll}\text { Excerpt } 3 & \text { Decision-making (Exploratory) } \\ \text { Fara: } & \text { Ok. Let's check our picture and words. } \\ \text { Salim: } & \text { Ok, ok. This is the global...global } \\ & \text { warming. } \\ & \text { [Halina: Global warming.] } \\ \text { Fara: } & \text { First...first... } \\ \text { Salim\&Halina: } & \text { Sea pollution. } \\ \text { Salim: } & \text { Sea pollution...and you, you see...This } \\ & \text { ship, this ship and oil...the...the...in } \\ & \text { sea...ship oil and we can see the...not } \\ & \text { jaws...the...the...dolphin la! (lines 270- } \\ & \text { 272) } \\ & \text { [Fara: Jaws. (Giggle)] } \\ & \text { Dolphin...dolphin...like...a }\end{array}$ jump...He, he don't like the oil. (line 274) [Halina: Jump, jump.]

Fara: Haa!

Salim: $\quad$ And you can see this rrr...smoke. [Halina: Industry.]

Halina: Industry factor.

Fara: $\quad$ Ok, industry factor.

Salim: Air pollution.

Fara: Number three?

Salim: Global warming. The sun...sun and did....what...rmm...sun the...

[Fara: Relate, relate...]

Halina: The war..

Salim: $\quad$ The light of sun to...

Fara: Sorry, I don't understand, what? This picture and this picture.

Salim: This picture like global (warming), global (warming) to someone...

Fara: $\quad$ Ohh...

Salim: Haa...Logging is what we like logging, logging rr... (ship)

Fara: $\quad$ Ok

Salim: $\quad$ This is drug. I think you know.

[Fara: Drug...drug.]

Fara: $\quad$ I know drug.

Salim: $\quad$ Land fill I think is like (dessert). Padang pasir.

[Halina: Ok, ok.]

Fara: $\quad$ Don't speak Malay ok.

Salim\&Fara: [giggle]

Salim: Hunger. We can see the... Not women. The people, the person who is very, very, very, very, very, very, poor, very, very, hungry. (lines 300-301)

[Halina: Women?]

Halina: Hungry.

Fara: What's meaning by hunger?

Salim: Hunger is...hunger is for people who are hungry. There's hunger...there's...the people. (lines 305-306)

Fara: $\quad$ So the picture show rr the people is, rrrr is hungry, ok.

[Salim: Hungry.]

Fara: $\quad$ Hungry, hungry, hungry.

Salim: $\quad$ You can see the rrr...car...the car around the world...That's mean, that shows the busy, busy person. (lines 310-311)

[Halina:The busy]

(DM2/Blue/265-312)

\subsection{Collaborative Interactions}

Episodes of collaborative interactions were evident as the participants jointly made meaning in order to understand the information and negotiated ideas. However, the kind of collaborative interactions generated differed from one task type to the other i.e. jigsaw and decisionmaking tasks. A different kind of collaborative interaction could be seen when the participants engaged in the decision-making task completion. When the participants jointly made meaning, their learner interactions were exploratory and highly collaborative with evidence of intensive negotiation. They negotiated ideas and provided extended explanation in order to achieve mutual understanding. When compared to the jigsaw learner interactions, despite being collaborative, their interactions were quite straight forward with some evidence of negotiation when engaged in jigsaw task completion. Excerpt 4 illustrates the collaborative interaction generated by the participants when they completed the decisionmaking task. They negotiated their ideas and together they tried to make meaning. Hartini pointed out the picture which she thought showed air pollution. The rest of the participants in the team agreed after a short discussion. Then Mohd shared his opinion regarding the picture that showed water pollution. However, Hartini expressed disagreement and provided her explanation. Jani and Mohd shared similar understanding and tried to convince Hartini by explaining to her. However, Hartini was adamant about what she thought and she tried to convince the others in her team. Eventually, they all agreed to have two types of pollution, water and sea pollution, as suggested by Mohd (lines 49-50). Evidence of raising questions and investigation of the materials can be seen in their learner interactions as they explored them together. Their learner interactions were highly collaborative with episodes of intensive negotiation.

$\begin{array}{ll}\text { Excerpt } 4 & \text { Decision-making (Joint Meaning-making) } \\ \text { Hartini: } & \text { The air pollution. } \\ \text { Mohd: } & \text { Air pollution? } \\ \text { Hartini: } & \text { Air pollution. } \\ \text { Jani: } & \text { Where? } \\ \text { Hartini: } & \text { This picture. } \\ \text { Jani: } & \text { Ha! }\end{array}$


Mohd: Air pollution?

Hartini: Yes.

Jani: $\quad$ Because this something apa, we call that?

Mohd: This is foreigner, eh, foreign.

Jani: $\quad$ Factory la!

Mohd: This is factory so I think foreign relate to air pollution.

Jani: $\quad$ Ok, then I think this $n i$ water because this in the water.

Mohd: $\quad$ Yes, I think also, excuse me, are you sure this picture water pollution because this is water and fish.

Jani: $\quad$ Then?

Mohd: And then I think this also, excuse me, I think this also what we call, this water pollution because.

Hartini: I think this water pollution. Sorry to interrupt, I think I don't agree with water pollution because this picture is good to water pollution.

Jani: I think may be yes because it show that something they throw, something to the water.

Mohd: $\quad$ Excuse me, sorry to interrupt, I think this is a water pollution and this like air, like at sea. (lines 49-50)

Hartini: Sorry to interrupt, I think this picture is sea pollution.

Jani: $\quad$ But this is impact of water pollution.

Hartini: Sea pollution.

Jani: $\quad$ Oh have two, water and sea pollution.

Mohd: Ok, what do you think that relate with sea pollution?

Jani: I think this sea, sea pollution because hasrumpai, doesn't look like water pollution.

Mohd: This water I think, this is water pollution.

(DM2/Brown/27-58)

\section{Discussion}

The research question concerned the kind of oral discourse generated through the use of different communication task types. Findings showed that when engaged in the jigsaw task type, learner interactions revealed an interplay between the procedural, productoriented activity and exploratory activity. By procedural, it means that the learner interactions were characterized by procedural handling of information, routine execution of tasks with some form of planning and organizing and was very much product-oriented. Talk revolving planning and organizing how to tackle tasks is considered particularly important as it stimulates individuals, provides them with an infrastructure to negotiate development, takes and manages control of their activity and learning, and guides them through the tasks (Swain, 2000). This was observed in Excerpt 1 . The exploratory activity on the other hand, was collaborative in nature with evidence of intensive negotiations.

In contrast, the learner interactions of the participants engaged in the decision-making task type was very exploratory in nature. They engaged in exploratory interactions when they approached and processed the decision-making tasks. The exploratory interactions were also very much characterized by intensive negotiation and were highly collaborative as seen in Excerpt 3. The importance of exploratory interaction in promoting learning is widely recognized (Cohen, 1994; Edwards \& Mercer, 1987; Mercer, 1994; Phillips, 1990; Wells, 1987). It is seen as an effective mode in fostering critical thinking and cognitive development (Mercer, 1996) and increases learners' awareness of strategies needed in the process of solving problems and that includes writing which includes problem posing and solving, organizing and questioning, planning, experimenting, hypothesis testing, arguing, evaluating and reasoning. Such features were extensively found in the learner interactions when engaged in the decision-making task but not so much during the jigsaw task completion.

Findings also showed that close collaboration was evident throughout their learner interactions for both task types. The collaborative interaction was highlighted by episodes of joint meaning-making and were characterized mainly by episodes of asking for clarification and asking for more explanation. These episodes gave evidence of joint meaning-making among them in trying to build and achieve inter-subjectivity (Wells, 1987). The element of inter-subjectivity is very much related to collaboration and occurs through constant negotiation. However, when observed closely, during the decision-making task completion the participants' learner interactions were exploratory and highly collaborative with evidence of intensive negotiation compared to when engaged in the jigsaw task completion. The participants negotiated ideas and provided extended explanation in order to achieve mutual understanding. Their interaction episodes were not straight forward as they took time to explain as seen in Excerpt 4. For this study, it was observed that the decisionmaking task type was the type that encouraged the production of complex patterns of interactions and the generation of more complex ideas.

Theoretically, findings from this study expand the notion of interaction. It was pointed out that an important aspect in the Interaction Hypothesis (Long, 1996) is the belief that interaction facilitates SLA. The hypothesis explains that when learners interact, they make both conversational and linguistic modifications. Closely related is the Output Hypothesis (Swain, 1985, 1995, 2005) which claims that the act of producing language (speaking or writing) constitutes part of the process of second language learning. These are achieved through the use of tasks. However, learner interactions showed that the participants engaged in talks that were exploratory in nature with intensive negotiation especially during the decision-making task completion. When they interacted, they did not just produce language and make modifications. They explored and generated ideas. Basturkmen (2002) argues that complex 
patterns of interactions found in episodes of negotiation for meaning are "important in enabling students to develop their own ideas in discussion" (p. 233). These patterns generate more complex ideas to emerge and to be negotiated in interaction as learners articulate thoughts and clarify thinking more clearly. It is these kinds of interactions that are important particularly for learners at the tertiary level and hence, should be encouraged.

\section{Conclusion}

This study examines the oral discourse generated by EFL learners of an institution of higher learning in Malaysia using two communication task types. Findings show that the different task types encouraged the production of different kinds of learner interactions. This knowledge adds to our understanding regarding the kind of oral discourse generated in an EFL setting using the two different communication task types. For language instructors, particularly those at tertiary institutions, knowledge regarding the task types that could be used not only to promote language acquisition but also to enhance learning in general, is important. Not only will they be able to assist learners in language acquisition using suitable task types, learners' learning could also be enhanced using similar task types. In this case, the decision-making task type.

While the findings from this study have its contribution, much more research is still needed. One obvious limitation of the study is related to the issue of generalizability. Due to the unique features/characteristics of the participants in the study, the results of this study cannot be taken to be representative of students in other institutions of higher learning nor can they be generalized to other L2 teaching and learning contexts. However, although generalizability of the study may be limited, there are elements of the findings which may be transferable to other research contexts which can still be of benefit to other researchers. As highlighted by Guba and Lincoln (1989), the issue in qualitative-interpretive research is transferability rather than generalizability. Hence, other researchers may transfer what is applicable, suitable and relevant to their EFL contexts and situations rather than make generalization.

Another limitation issue is related to the tasks used. The focus of this study was on two different task types, i.e. jigsaw and decision-making task types. As found in the results of the study, different task types encouraged different kinds of learner interactions. Thus, by using other task types and examining learner interactions during task performance and completion, it is believed that a more comprehensive and complete set of data on the learners' oral discourse could be obtained. Data could be analyzed in order to understand the influence that other task types may have on the learners' oral discourse, the language learning opportunities the other task types may create and the value of other communication task types as a source for possible restructuring of inter-language which may lead to uptake of language input in an EFL tertiary setting. These findings may assist practitioners in planning tasks that may best suit their learners based on the objectives and aims intended for the learners. In closing, results from this study show that communication tasks could be used effectively in an EFL tertiary classroom in generating oral discourse among learners and promoting language development.

\section{References}

[1] Basturkmen, H. (2002). Negotiating meaning in seminartype discussion and EAP. English for Specific Purposes, 21, 233-242.

[2] Blake, R. (2000). Computer mediated communication: A window on L2 Spanish interlanguage. Language Learning and Technology, 4(1), 120-136.

[3] Cohen, E. (1994). Restructuring the classroom: Conditions for productive small groups. Review of Educational Research, 64(1), 1-35.

[4] de la Colina, A. A. \& Garcia Mayo, M. P. (2007). Attention to form across collaborative tasks by low-proficiency learners in an EFL setting. In M. P. Garcia Mayo (ed.), Investigating tasks in formal language learning (91 - 116). Clevedon, UK: Multilingual Matters.

[5] Edwards, D. \& Mercer, N. (1987). Common knowledge: The development of understanding in the classroom. London: Methuen.

[6] Ellis, R. (2004). Task-based language learning. Oxford: Oxford University Press.

[7] Garcia Mayo, M. P. (2007). Tasks, negotiation, and L2 learning in a foreign language context. In M. P. Garcia Mayo (ed.), Investigating tasks in formal language learning (69 - 90). Clevedon, UK: Multilingual Matters.

[8] Gass, S. M. \&Varonis, E. M. (1994). Input, interaction, and second language production. Studies in second language acquisition, 16, 283-302.

[9] Guba, E. \& Lincoln, Y. (1989). Fourth generation evaluation. CA: Sage Publications.

[10] Iwashita, N. (2003). Negative feedback and positive evidence in task-based interaction: Differential effects on L2 development. Studies in Second Language Acquisition, 25, $1-36$.

[11] Kowal, M \& Swain, M. (1997). From semantic to syntactic processing. How can we promote it in the immersion classroom? In R. K. Johnson \& M. Swain (eds.), Immersion education: International perspectives (284-309). Cambridge: Cambridge University Press.

[12] Kumpulainen, K. \& Wray, D. (2002). (eds). Classroom interaction and social learning: from theory to practice. New York: Routledge Falmer.

[13] Long, M. H. (1983). Linguistic and Conversational Adjustments to Nonnative Speakers. Studies in Second Language Acquisition, 5, 177-193.

[14] Long, M. H. (1985). Input and second language acquisition theory. In S. Gass and C. Madden (Eds.), Input and second language acquisition (377-393). Rowley, MA: Newbury House. 
[15] Long, M. H. (1996). The role of the linguistic environment in second language acquisition. In W. Ritchie and T.K. Bhatia (Eds.), Handbook of research on language acquisition: Second language acquisition volume 2 (413468). New York: Academic Press.

[16] Long, M. H. \& Robinson, P. (1998). Focus on form: Theory, research, and practice. In C. Doughty \& J. Williams (Eds.). Focus on form in classroom second language acquisition (15-41). New York: Cambridge University Press.

[17] Mackey, A. \&Gass, S. M. (2006). Introduction. Studies in Second Language Acquisition, 28(2), 169-178.

[18] Mackey, A., Oliver, R. \&Leeman, J. (2003). Interactional input and the incorporation of feedback: An exploration of NS-NNS and NNS-NNS adult and child dyads. Language Learning, 53(1), $35-66$.

[19] Mercer, N. (1994). The quality of talk in children's joint activity at the computer. Journal of Computer Assisted Learning, 10, 24-32.

[20] Mercer, N. (1996). The quality of talk in children's collaborative activity in the classroom. Learning and Instruction, 6, 359-377.

[21] Nakahama, Y., Tyler, A. \& Van Lier, L. (2001). Negotiation of meaning in conversational and information gap activities: A comparative discourse analysis. TESOL Quarterly, 35(3), $377-405$.

[22] Olsen, J. W-B \& Kagan, S. (1992). About cooperative learning. In Kessler, C. (Ed), Cooperative language learning. New Jersey: Prentice Hall Inc.

[23] Pica, T. (1992). The textual outcomes of native-speaker-nonnative-speaker negotiation: What do they reveal about second language learning? In C. Kramsch\& S. McConnellGinet (Eds.), Text and Context (198-237). Cambridge, MA: Heath.

[24] Pica, T. \& Doughty, C. (1985). Input and interaction in the communicative language classroom: A comparison of teacher-fronted and group activities. In S. M. Gass\& C. G. Madden (Eds.), Input in second language acquisition (115132). Rowley, MA: Newbury House.

[25] Pica, T., Kanagy, R. \&Falodun, J. (1993). Choosing and using communicative tasks for second language instruction. In Crookes, G. \&Gass, S. (Eds.), Tasks and language learning: Integrating theory and practice (9-34). Clevedon, UK: Multilingual Matters.

[26] Phillips, T. (1990). Structuring context for exploratory talk. In D. Wray (Ed.), Talking and Listening (60-72). Leamington Spa: Scholastic.

[27] Smith, B. (2003). Computer-mediated negotiated interactions: An expanded model. Modern Language Journal, $87,38-57$
[28] Swain, M. (1985) Communicative competence: Some roles of comprehensible input and comprehensible output in its development. In S. Gass\& C. Madden (Eds), Input in Second Language Acquisition (235-253). Rowley, MA: Newbury House.

[29] Swain, M. (1995). Three functions of output in second language learning. In G. Cook \& B. Seidhofer (Eds.), Principles and practice in the study of language (125-144). Oxford: Oxford University Press.

[30] Swain, M. (1998). Focus on form through conscious reflection. In Doughty, C. \& Williams, J. (Eds.), Focus on form in classroom second language acquisition (64-81). Cambridge: Cambridge University Press.

[31] Swain, M. (2000). The output hypothesis and beyond: Mediating acquisition through collaborative dialogue. In P. Lantolf (Ed.), Sociocultural theory and second language learning (97-114). Oxford: Oxford University Press.

[32] Swain, M. (2001). Integrating language and content teaching through collaborative tasks. The Canadian Modern Language Review, 58, $44-63$.

[33] Swain, M. (2005). The output hypothesis: Theory and research. In E. Hinkel (Ed.), The handbook of research in second language teaching and learning (471-483). Mahwah,NJ: Erlbaum.

[34] Swain, M. \&Lapkin, S. (1995). Problems in output and the cognitive processes they generate: a step toward second language learning. Applied Linguistics, 16, 371-391.

[35] Swain, M. \&Lapkin, S. (1998). Interaction and second language learning: two adolescent French immersion students working together. The Modern Language Journal, $82,320-337$.

[36] Swain, M. \&Lapkin, S. (2000). Task-based second language learning: The uses of the first language. Language Teaching Research, 4(3), 251-274.

[37] Swain, M. \&Lapkin, S. (2001). Focus on form through collaborative dialogue: Exploring task effects. In Bygate, M., Skehan, P. \& Swain, M. (Eds.), Researching pedagogic tasks: Second language learning, teaching and testing (99-118). Essex, UK: Pearson Education Limited.

[38] Tabatabaei, S. O. (2009). The impact of task type and gender on total incidence of negotiation for meaning. The Journal of Applied Linguistics, 2(1), 238 - 270.

[39] Wells, G. (1987). The meaning makers: children learning language and using language to learn. Portsmouth: Heinemann Educational Books Inc. 